\title{
KONTRIBUSI KECERDASAN EMOSIONAL DAN DISIPLIN BELAJAR TERHADAP HASIL BELAJAR TEKNOLOGI INFORMASI DAN KOMUNIKASI (TIK)
}

\author{
Linda Fitria $^{\mathbf{1}}$ ), Menrisal ${ }^{\mathbf{2}}$ ) \\ Universitas Putra Indonesia YPTK Padang \\ Email:lindafitria@upiyptk.ac.id
}

\begin{abstract}
Abstrak Penelitian ini bertujuan untuk mengetahui seberapa besar kontribusi kecerdasan emosional dan disiplin belajar terhadap hasil belajar TIK siswa kelas XI di SMA Negeri 12 Padang. Jenis penelitian ini adalah kuantitatif dengan menggunakan metode penelitian korelasional. Penelitian ini dilakukan di SMA Negeri 12 Padang semester ganjil tahun pelajaran 2016/2017. Populasi dalam penelitian ini yaitu seluruh siswa kelas XI di SMA Negeri 12 Padang. Teknik pengambilan sampel yang digunakan adalah proporsional random sampling. Yang terpilih menjadi sampel dalam penelitian ini berjumlah 115 orang siswa.

Berdasarkan hasil penelitian, diketahui bahwa kontribusi kecerdasan emosional terhadap hasil belajar TIK sebesar 3,61\%. Sedangkan kontribusi disiplin belajar terhadap hasil belajar TIK sebesar $6,96 \%$. Serta kontribusi kecerdasan emosional dan disiplin belajar terhadap hasil belajar TIK sebesar 8,2\%. Dari uji analisis data didapatkan bahwa data normal dan linier. Hasil pengujian pada taraf signifikansi $\alpha 0,05$ (taraf kepercayaan 95\%) didapatkan nilai $\mathrm{rx}_{1}$ ysebesar 0,190 dengan rtabel 0,184 karena rhitung > rtabel maka hipotesis pertama diterima. Kemudian nilai $\mathrm{rx}_{2} \mathrm{y}$ sebesar 0,264 dengan rtabel 0,184, karena rhitung $>$ rtabel maka hipotesis kedua diterima. Selanjutnya nilai $\mathrm{rx}_{1} \mathrm{X}_{2} \mathrm{y}$ sebesar 0,286 dengan rtabel 0,184 , karena rhitung > rtabel maka hipotesis ketiga diterima. Dan didukung oleh nilai $F_{\text {hitung }}=5,125$ dan $F_{\text {tabel }}=1,364$ sehingga diperoleh $F_{\text {hitung }}>F_{\text {tabel }}$ $(5,125>1,364)$. Dengan demikian hipotesis ketiga diterima, yang berarti bahwa terdapat kontribusi yang yang positif dan signifikan kecerdasan emosional dan disiplin belajar terhadap hasil belajar TIK siswa kelas XI di SMA Negeri 12 Padang.
\end{abstract}

Kata Kunci: kecerdasan emosional, disiplin belajar, hasil belajar

\section{PENDAHULUAN}

Pendidikan pada hakikatnya adalah usaha sadar dan terencana untuk mewujudkan suasana belajar dan proses pembelajaran agar peserta didik secara aktif mengembangkan potensi dirinya untuk memiliki kekuatan spiritual keagamaan, pengendalian diri, kepribadian, kecerdasan, akhlak mulia, serta ketrampilan yang diperlukan dirinya, masyarakat, bangsa dan Negara .

Sekolah Menengah Atas (SMA) merupakan salah satu jenjang pendidikan formal yang bertujuan untuk mempersiapkan siswa menjelang pendidikan tinggi. Pada pendidikan formal keberhasilan proses belajar mengajar dapat dilihat dari hasil belajar yang diperoleh siswa. Hasil belajar siswa pada hakikatnya adalah perubahan tingkah laku. Tingkah laku sebagai hasil belajar dalam pengertian yang luas mencakup bidang kognitif, afektif dan psikomotoris (Sudjana, 1995). Hasil belajar merupakan bentuk keberhasilan siswa dalam mengikuti proses belajar mengajar (Gulo, 2008).
Hasil belajar siswa dipengaruhi oleh faktor internal dan faktor eksternal (Nasional, 2006). Faktor internalnya yaitu faktor fisiologis dan psikologis. Faktor fisiologis adalah faktor-faktor yang berhubungan dengan kondisi fisik individu. Faktor psikologis adalah keadaan psikologis seseorang yang dapat mempengaruhi proses belajar. Beberapa faktor psikologis yang utama mempengaruhi proses belajar adalah kecerdasan emosional siswa, motivasi, minat, disiplin belajar, aspirasi sikap dan bakat (Pendidikan, 1993). Sedangkan faktor eksternal adalah faktor dari luar diri anak yang ikut mempengaruhi belajar anak. Faktor eksternal digolongkan menjadi dua bagian yaitu lingkungan sosial dan lingkungan non sosial (SUMENEP, 2009).

Salah satu faktor internal yang mempengaruhi hasil belajar adalah kecerdasan emosional (Daud, 2012). Kecerdasan emosional adalah kemampuan untuk mengenali perasaan kita sendiri dan perasaan orang lain, kemampuan untuk memotivasi diri sendiri dan kemampuan untuk mengelola emosi dengan baik pada diri sendiri dan dalam hubungan/berinteraksi dengan orang lain (Goleman, 2000). Selain kecerdasan 
emosional, disiplin belajar juga tergolong faktor HASIL

internal yang mempengaruhi keberhasilan belajar.

Disiplin belajar merupakan suatu bentuk kesadaran diri untuk mengendalikan diri dengan aturan-aturan yang berlaku (Fitria, 2016). Dalam hal ini, disiplin belajar berfungsi sebagai pengendali diri yang berada pada diri orang tersebut sehingga belajar akan penuh kesadaran, tanpa paksaan dan penuh sukacita/bersyukur.

Berdasarkan hasil observasi dan wawancara yang dilakukan pada bulan terhadap siswa kelas XI di SMA Negeri 12 Padang genap tahun pelajaran 2015/2016, dapat diketahui bahwa masih banyak siswa yang bersikap labil dalam menyikapi berbagai masalah dalam belajar. Hal ini terlihat dari cara mereka menyikapi proses belajar mengajar.

\section{METODE PENELITIAN}

Penelitian ini menggunakan jenis penelitian kuantitatif korelasional. Metode penelitian kuantitatif merupakan penelitian ilmiah yang sistematis terhadap bagian-bagian dan fenomena serta hubungan-hubungannya. Tujuan penelitian kuantitatif adalah mengembangkan dan menggunakan model-model matematis, teori-teori dan/atau hipotesis yang berkaitan dengan fenomena alam. Proses pengukuran adalah bagian yang sentral dalam penelitian kuantitatif karena hal ini memberikan hubungan yang fundamental antara pengamatan empiris dan ekspresi matematis dari hubunganhubungan kuantitatif. Sedangkan metode penelitian korelasional adalah suatu penelitian yang melibatkan tindakan pengumpulan data guna menentukan, apakah ada hubungan dan tingkat hubungan antara dua variabel atau lebih. Adanya hubungan dan tingkat variabel ini penting, karena dengan mengetahui tingkat hubungan yang ada, peneliti akan dapat mengembangkannya sesuai dengan tujuan penelitian (Suharsimi, Arikunto: 2013).

Penelitian ini bertujuan melihat kontribusi kecerdasan emosional dan disiplin belajar terhadap hasil belajar Teknologi Informasi dan Komunikasi (TIK) siswa kelas XI di SMA Negeri 12 Padang semester ganjil tahun pelajaran 2016/2017.

\section{Kecerdasan Emosional $\left(\mathbf{X}_{1}\right)$}

Data variabel kecerdasan emosional dikumpulkan melalui angket yang terdiri dari 32 butir pernyataan yang telah diuji validitas dan reliabilitasnya. Selanjutnya angket diberikan kepada 115 orang responden untuk diisi. Dari data penelitian diketahui bahwa distribusi skor jawaban menyebar terendah 95 dan tertinggi 159.

Berdasarkan distribusi skor tersebut didapat rata-rata (mean) sebesar 132,200 skor tengah (median) 137, skor yang banyak muncul (mode) 129, varians 210,933 dan simpangan baku (standar deviasi) 14,523. Berikut merupakan gambaran yang jelas tentang distribusi skor tentang kecerdasan emosional, dapat dilihat pada tabel 13 dan Gambar 2:

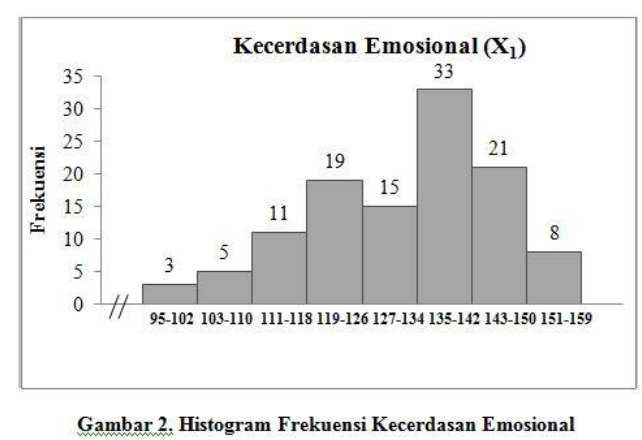

Berdasarkan tabel 13 terlihat distribusi frekuensi variabel $\mathrm{X}_{1}$ yaitu kecerdasan emosional, dimana dalam menentukan hitungan jarak atau rentang, jumlah kelas interval serta panjang kelas dapat dilihat pada lampiran 22. Berikut histogramnya, yaitu: 
Tabel 13. Distribusi Frekuensi Variabel Kecerdasan Emosional

\begin{tabular}{|c|c|c|c|c|}
\hline \multirow[b]{2}{*}{ No } & \multicolumn{4}{|c|}{ Variabel $X_{1}$} \\
\hline & $\begin{array}{l}\text { Interval } \\
\text { Skor }\end{array}$ & $\begin{array}{c}\text { Frekuensi } \\
\text { Mutlak }\end{array}$ & $\begin{array}{c}\text { Frekuensi } \\
\text { Relatif (\%) }\end{array}$ & $\begin{array}{c}\text { Frekuensi } \\
\text { Kumulatif (\%) }\end{array}$ \\
\hline 1 & $95-102$ & 3 & 2,61 & 2,61 \\
\hline 2 & $103-110$ & 5 & 4,35 & 6,96 \\
\hline 3 & $111-118$ & 11 & 9,57 & 16,52 \\
\hline 4 & $119-126$ & 19 & 16,52 & 33,04 \\
\hline 5 & $127-134$ & 15 & 13,04 & 46,09 \\
\hline 6 & $135-142$ & 33 & 28,70 & 74,78 \\
\hline 7 & $143-150$ & 21 & 18,26 & 93,04 \\
\hline 8 & $151-159$ & 8 & 6,96 & 100,00 \\
\hline & umlah & 115 & 100 & \\
\hline
\end{tabular}

\section{Disiplin Belajar $\left(\mathbf{X}_{2}\right)$}

Data variabel disiplin belajar dikumpulkan melalui butir pernyataan angket yang terdiri dari 30 butir pernyataan yang telah diuji validitas dan reliabilitasnya. Selanjutnya angket diberikan kepada 115 orang responden untuk diisi. Dari data penelitian diketahui bahwa distribusi skor terendah 91 dan tertinggi 150. Berdasarkan distribusi skor tersebut didapat rata-rata (mean) sebesar 124,339 skor tengah (median) 126, skor yang banyak muncul (mode) 125, varians sebesar 225,437 dan simpangan baku (standar deviasi) 15,015. Berikut merupakan gambaran yang jelas tentang distribusi skor disiplim belajar, dapat dilihat pada tabel 14 dan gambar 3 berikut ini:

Tabel 14. Distribusi Frekuensi Variabel Disiplin Belajar

\begin{tabular}{|c|c|c|c|c|}
\hline \multirow[b]{2}{*}{ No } & \multicolumn{4}{|c|}{ Variabel $\mathrm{X}_{2}$} \\
\hline & $\begin{array}{c}\text { Interval } \\
\text { Skor }\end{array}$ & $\begin{array}{c}\text { Frekuensi } \\
\text { Mutlak }\end{array}$ & $\begin{array}{l}\text { Frekuensi } \\
\text { Relatif (\%) }\end{array}$ & $\begin{array}{c}\text { Frekuensi } \\
\text { Kumulatif (\%) }\end{array}$ \\
\hline 1 & $91-98$ & 6 & 5,22 & 5,22 \\
\hline 2 & $99-106$ & 12 & 10,43 & 15,65 \\
\hline 3 & $107-114$ & 19 & 16,52 & 32,17 \\
\hline 4 & $115-122$ & 11 & 9,57 & 41,74 \\
\hline 5 & $123-130$ & 28 & 24,35 & 66,09 \\
\hline 6 & $131-138$ & 20 & 17,39 & 83,48 \\
\hline 7 & $139-146$ & 14 & 12,17 & 95,65 \\
\hline 8 & $147-154$ & 5 & 4,35 & 100,00 \\
\hline & umlah & 115 & 100 & \\
\hline
\end{tabular}

Berdasarkan gambar 3 diperoleh gambaran bahwa interval skor tertinggi pada kelas interval 123-130 dengan frekuensi sebesar 28 orang atau sebesar $24,35 \%$

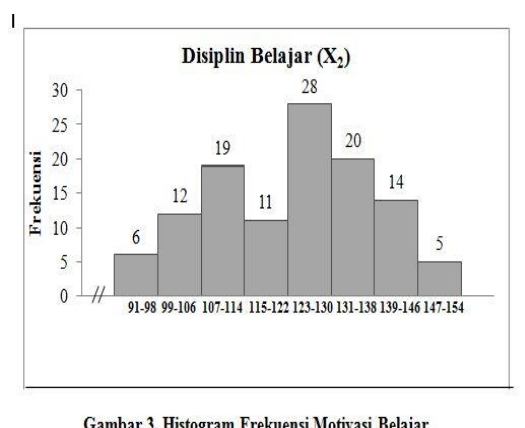

\section{Hasil Belajar TIK (Y)}

Data variabel hasil belajar TIK dikumpulkan melalui butir soal yang terdiri dari 30 butir soal yang telah diuji validitas dan reabilitasnya serta indeks kesukaran dan daya bedanya. Selanjutnya soal diberikan kepada 115 orang responden untuk diisi. Dari data penelitian diketahui bahwa distribusi skor terendah 67 dan tertinggi 100. Berdasarkan distribusi skor tersebut didapat rata-rata (mean) sebesar 84,435 skor tengah (median) 86 , skor yang banyak muncul (mode) 125, varians sebesar 78,985 dan simpangan baku (standar deviasi) 8,887 . Berikut ini gambarannya pada tabel 15 dan gambar 4 berikut ini:

\begin{tabular}{|c|c|c|c|c|}
\hline \multirow[b]{2}{*}{ No } & \multicolumn{4}{|c|}{ Variabel Y } \\
\hline & $\begin{array}{c}\text { Interval } \\
\text { Skor }\end{array}$ & $\begin{array}{c}\text { Frekuensi } \\
\text { Mutlak }\end{array}$ & $\begin{array}{l}\text { Frekuensi } \\
\text { Relatif (\%) }\end{array}$ & $\begin{array}{c}\text { Frekuensi } \\
\text { Kumulatif (\%) }\end{array}$ \\
\hline 1 & $61-65$ & 0 & 0,00 & 0,00 \\
\hline 2 & $66-70$ & 9 & 7.83 & 7,83 \\
\hline 3 & $71-75$ & 10 & 8,70 & 16,52 \\
\hline 4 & $76-80$ & 25 & 21.74 & 38,26 \\
\hline 5 & $81-85$ & 17 & 14,78 & 53,04 \\
\hline 6 & $86-90$ & 28 & 24,35 & 77,39 \\
\hline 7 & $91-95$ & 10 & 8,70 & 86,09 \\
\hline 8 & $96-100$ & 16 & 13,91 & 100,00 \\
\hline & umlah & 115 & 100 & \\
\hline
\end{tabular}

Berdasarkan gambar 4 diperoleh gambaran bahwa interval skor tertinggi pada kelas interval 810 85 dengan frekuensi sebesar 28 orang atau sebesar $24,347 \%$.

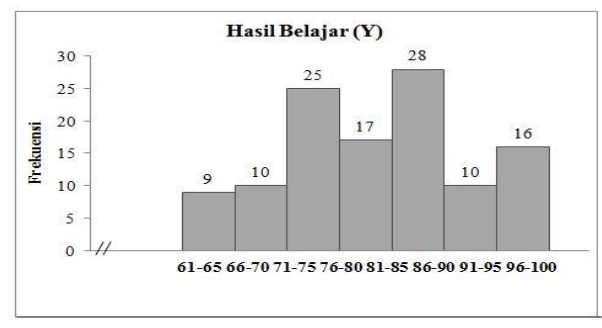

Gambar 4. Histogram Frekuensi Hasil Belajar 
Berdasarkan gambar 4 diperoleh gambaran bahwa interval skor tertinggi pada kelas interval 810-85 dengan frekuensi sebesar 28 orang atau sebesar $24,347 \%$.

\section{Uji Persyaratan Analisis \\ a. Uji Normalitas}

Uji normalitas digunakan untuk mengetahui apakah populasi data berdistribusi normal atau tidak. Uji normalitas dilakukan dengan menggunakan rumus Liliefors yang dihitung secara manual. Hasil uji normalitas dapat dilihat pada tabel 16 berikut (dapat dilihat pada lampiran 15 ):

\section{Tabel16. Vilai Uji. Normalitas}

\begin{tabular}{ccccccc}
\hline No. & Kelas & $\mathrm{N}$ & $\mathrm{L}_{0}$ & $\mathrm{~L}_{\mathrm{t}}$ & Perbandingan & Ket \\
\hline 1. & $\mathrm{X}_{1}$ & 161 & 0,0014 & 0,0826 & $\mathrm{~L}_{\text {hitung }} \mathrm{L}_{\text {tabel }}$ & Normal \\
\hline 2. & $\mathrm{X}_{2}$ & 161 & 0,0046 & 0,0826 & $\mathrm{~L}_{\text {hitung }} \mathrm{L}_{\text {tabel }}$ & Normal \\
\hline 3. & $\mathrm{Y}$ & 161 & $-0,0011$ & 0,0826 & $\mathrm{~L}_{\text {hitung }} \mathrm{L}_{\text {tabel }}$ & Nomal \\
\hline
\end{tabular}

Dari tabel 16 dapat dilihat bahwa skor signifikansi untuk kecerdasan emosional dan disiplin belajar terhadap hasil belajar TIK siswa diperoleh $\mathrm{L}_{0}$ untuk variabel $\mathrm{X}_{1}$ (kecerdasan emosional) sebesar 0,0014, untuk variabel $\mathrm{X}_{2}$ (disiplin belajar) sebesar 0,0046 dan $\mathrm{L}_{0}$ untuk variabel $\mathrm{Y}$ (Hasil Belajar) sebesar -0,0011. Sedangkan nilai $L_{t}$ adalah 0,0826 yang diperoleh dari nilai kritis L untuk uji Liliefors. Karena hasilnya Lhitung $<$ Ltabel maka sampel dikatakan berdistribusi normal. Perhitungan dapat dilihat pada lampiran 15, maka prasyarat uji hipotesis selanjutnya dapat dilakukan.

\section{b. Uji Linieritas}

Uji linieritas bertujuan untuk mengetahui apakah variabel kecerdasan emosional $\left(\mathrm{X}_{1}\right)$ dan disiplin belajar $\left(\mathrm{X}_{2}\right)$ mempunyai kontribusi yang linear atau tidak secara signifikan terhadap variabel hasil belajar $(\mathrm{Y})$. Uji linieritas biasanya digunakan sebagai persyaratan dalam analisis korelasi atau regresi linear. Dapat dikatakan hubungan linear secara signifikansi antar variabel bila signifikansi lebih besar dari alpha (0.05). Hasil uji linearitas data dapat dilihat pada tabel 17 berikut (dapat dilihat pada lampiran 16).

Tabel 17. Hasil Uji Linearitas Data

\begin{tabular}{ccccc}
\hline Variabel & Sig. & Fhitung & Ftabel & Kriteria \\
\hline $\mathrm{X}_{1}-X_{2}-Y$ & 0,05 & 1,375 & 1,364 & Linear \\
\hline
\end{tabular}

Berdasarkan tabel hasil uji liniaritas diatas diperoleh nilai $F_{\text {hitung }}=1,375$ sedangkan $F_{\text {tabel }}=1,364$ yang diperoleh dari distribution table Nilai $\mathrm{F}$ pada signifikansi 0,05 . Karena nilai $F_{\text {hitung }}$ lebih besar dari $F_{\text {tabel }}$ maka dapat disimpulkan bahwa terdapat hubungan linear secara signifikan antara variabel kecerdasan emosional $\left(\mathrm{X}_{1}\right)$ dan disiplin belajar $\left(\mathrm{X}_{2}\right)$ terhadap hasil belajar (Y). Maka dengan demikian uji hipotesis dapat dilaksanakan.

\section{c. Uji Hipotesis}

\section{Korelasi Sederhana}

Ujikorelasi ederhana dilakukan untuk menyatakan berapa besar hubungan antara satu variabel bebas dan satu variabel terikat. Uji hipotesis bertujuan untuk menguji apakah hipotesis yang diajukan diterima atau ditolak. Rumus yang digunakan dalam pengujian ini adalah rumus korelasi Product Moment oleh (Anas Sudijono, 2011). Hasil uji korelasi sederhana dapat dilihat berdasarkan lampiran 17. Uji korelasi sederhana dilakukan dengan menggunakan rumus uji korelasi Product Moment, dari hasil pengujian korelasi Product Moment didapatkan nilai $r_{\text {hitung }}$ kemudian dibandingkan dengan $r_{\text {tabel. }}$.

\section{Korelasi Ganda}

Uji korelasi gandadilakukan untuk menyatakan berapa besar hubungan antara dua variabel bebas atau lebih dan satu variabel terikat. Sebelum mencari nilai $F$, terlebih dahulu dicari nilai korelasi product moment antara ketiga variabel tersebut yaitu $\mathrm{Rx}_{1} \mathrm{x}_{2} \mathrm{y}$.

d. KoefisienDeterminasi $\left(r^{2}\right)$

Penentuan seberapa besar pengaruh antara variabel independen 
terhadap variabel dependen yang Padang semester ganjil tahun pelajaran ditunjukan oleh besarnya koefisien 2016/2017 yaitu sebesar 8,2\%. Sebagaimana determinasi. Berdasarkan output dapat dijelaskan melalui nilai $F_{\text {hitung }}$ pada nilai $\mathrm{r}^{2}$ pada lampiran 17 penelitian ini yaitu 5,125 dengan $\mathrm{F}_{\text {tabel }} 1,364$ menunjukan angka sebesar $8,2 \%$ diketahui bahwa variabel $\mathrm{X}_{1}$ (kecerdasan artinya persentase sumbangan emosional) dan variabel $\mathrm{X}_{2}$ (disiplin belajar) kecerdasan emosional (Variabel $\mathrm{X}_{1}$ ) memiliki hubungan yang positif dan signifikan dan disiplin belajar $\left(\mathrm{X}_{2}\right)$ terhadap terhadap variabel $\mathrm{Y}$ (Hasil Belajar). Maka dapat hasil belajar TIK (Variabel Y) disimpulkan bahwa hipotesis pertama, kedua dan sebesar 8,6\%. Dapat ditarik ketiga diterima.

kesimpulan bahwa hubungan antara Penelitian ini relevan dengan skripsi karya variabel $X_{1}$ dan $X_{2}$ terhadap variabel Rina Oktavia. (2015). Skripsi yang berjudul“ Y memberikan kontribusi sebesar Korelasi Kecerdasan Emosional dan Motivasi $8,6 \%$.

\section{PEMBAHASAN}

Hasil analisis penelitian ini berisi tentang deskripsi data kecerdasan emosional dan disiplin belajar terhadap hasil belajar TIK. Dimana kecerdasan emosional adalah kemampuan lebih yang dimiliki seseorang dalam memotivasi diri, ketahanan dalam meghadapi kegagalan, mengendalikan emosi dan menunda kepuasan, serta mengatur keadaan jiwa (Daniel Goleman, 2005). Sedangkan disiplin belajar adalah suatu kondisi yang sangat penting dan menentukan keberhasilan seorang siswa dalam proses belajarnya. Disiplin merupakan titik pusat dalam pendidikan, tanpa disiplin tidak akan ada kesepakatan antara guru dan siswa yang mengakibatkan prestasi yang dicapai kurang optimal terutama dalam belajar (Tu'u, 2004). Selanjutnya hasil belajar adalah perubahan tingkah laku. Tingkah laku sebagai hasil belajar dalam pengertian yang luas mencakup bidang kognitif, afektif dan psikomotoris (Nana Sudjana, 2009:3).

Berdasarkan penelitian ini diketahui hubungan kecerdasan emosional $\left(\mathrm{X}_{1}\right)$ dan disiplin belajar $\left(\mathrm{X}_{2}\right)$ terhadap hasil belajar TIK (Y) siswa kelas XI di SMA Negeri 12 Padang semester genap tahun pelajaran 2016/2017 adalah sebesar $8,2 \%$ yang berada dalam kategori sedang. Hasil analisis data dan pengujian hipotesis menunjukan bahwa hipotesis yang diuji dalam penelitian ini diterima. Dengan demikian maka variabel $\mathrm{X}_{1}$ (kecerdasan emosional) dan $\mathrm{X}_{2}$ (disiplin belajar belajar) memiliki hubungan yang positif dan signifikan terhadap variabel Y (Hasil Belajar).

Pada penelitian ini membahas kecerdasan emosional (Variabel $\mathrm{X}_{1}$ ) dan disiplin belajar $\left(\mathrm{X}_{2}\right)$ memberikan hubungan yang cukup terhadap hasil belajar TIK siswa kelas XI di SMA Negeri 12
Belajar Terhadap Disiplin Belajar Teknologi Informasi dan Komunikasi Kelas X di SMA Adabiah 2 Padang Semester Genap Tahun Pelajaran 2014/2015."

\section{SIMPULAN}

Berdasarkan hasil analisis penelitian tentang hubungan kecerdasan emosional (X1) dan disiplin belajar (X2) terhadap hasil belajar TIK (Y) siswa kelas XI di SMA Negeri 12 Padang, maka dapat ditarik kesimpulan yaitu:

1. Terdapat kontribusi yang positif dan signifikan antara kecerdasan emosional terhadap hasil belajar TIK siswa kelas XI di SMA Negeri 12 Padang.

2. Terdapat kontribusi yang positif dan signifikan antara disiplin belajar terhadap hasil belajar TIK siswa kelas XI di SMA Negeri 12 Padang.

3. Terdapat kontribusi yang positif dan signifikan antara kecerdasan emosional dan disiplin belajar secara bersama-sama terhadap hasil belajar TIK siswa kelas XI di SMA Negeri 12 Padang.

Berdasarkan perhitungan uji korelasi berganda menunjukkkan bahwa hasilnya adalah $r_{\text {hitung }>\text { rtabel }}(0,286>0,184)$. Sehingga dapat ditarik kesimpulan bahwa hubungan dikatakan positif, dan dapat dilanjukan dengan uji signifikan. Uji signifikan dicari dengan menggunakan uji $\mathrm{F}$, sehingga diperoleh hasil dengan $\mathrm{F}_{\text {hitung }}=5,125$ sedangkan $\mathrm{F}_{\text {tabel }}=1,364$ $\left(F_{\text {hitung }}>\mathrm{f}_{\text {tabel }}\right)$. Nilai tersebut memberikan kesimpulan bahwa terdapat kontribusi yang positif dan signifikan antara kecerdasan emosional dan disiplin belajar secara bersamasama terhadap hasil belajar TIK siswa kelas XI di SMA Negeri 12 Padang semester ganjil tahun pelajaran 2016/2017.Berdasarkan penjelasan di atas dapat ditarik kesimpulan 
bahwa hipotesis ketiga dalam penelitian ini Sugiyono. 2013. Metode Penelitian Kuantitatif diterima.

\section{SARAN}

Setelah dilaksanakan penelitian tentang hubungan kecerdasan emosional (X1) dan Suharsimi, Arikunto. 2013. Prosedur Penelitian. disiplim belajar (X2) terhadap hasil belajar TIK (Y) siswa kelas XI di SMA Negeri 12 Padang. Maka diberikan beberapa saran, yaitu:

Kualitatif dan R\&D. Bandung: Alfabeta.

Suhardi. 2009. Teknologi Informasi dan Komunikasi di Indonesia. Jakarta :Rajawali Pers.

1. Bagi guru, diharapkan penelitian ini dapat Syaiful, Sagala. 2013. Konsep dan Makna dijadikan litaratur dalam memperbaiki cara mengajar di kelas.

2. Bagi peneliti selanjutnya, diharapkan peneliti selanjutnya dapat menjadikan hasil penelitian ini sebagai penelitian yang relevan dan dapat menggunakannya sebagai referensi di lampiran. Jakarta: Rineka Cipta.

Syah. 2003. Hasil Belajar Siswa. Jakarta :Rajawali Pers.

. Bagi penulis, diharapkan penulis dapat Pembelajaran. Bandung: Alfabeta.

Triyono. 2012. Metodologi Penelitian Pendidikan. Yogyakarta: Ombak.

Tu'u. 2004. Disiplin Peserta Didik. Bandung: Remaja Rosdakarya.

Zainal. 2009. Ciri Siswa yang Disiplin. Bandung: Remaja Rosdakarya. memperkuat ilmu penulis melalui penulisan karya ilmiah ini.

\section{DAFTAR RUJUKAN}

Anas, Sudijono. 2011. Pengantar Evaluasi Pendidikan. Jakarta :Rajawali Pers.

Cooper \& Syawaf. 2009. Kecerdasan Emosional dan Pembagiannya. Jakarta: Rineka Cipta.

Daniel, Goleman. 2005. Kecerdasan Emosional. Bandung: Alfabeta.

Daud, F. (2012). Pengaruh kecerdasan emosional (EQ) dan motivasi belajar terhadap hasil belajar Biologi siswa SMA 3 Negeri Kota Palopo. Jurnal Pendidikan dan Pembelajaran (JPP), 19(2), 243-255.

Fitria, L. (2016). Hubungan antara pengasuhan orangtua dengan penyesuaian diri siswa terhadap peraturan sekolah. Ristekdik: Jurnal Bimbingan dan Konseling, 1(2).

Goleman, D. (2000). Kecerdasan emosional: Gramedia Pustaka Utama.

Gulo, W. (2008). Strategi Belajar Mengajar (Cover Baru): Grasindo.

Harmoko. 2005. Cara Membaca Kecerdasan Emosi Anak. Jakarta :Rajawali Pers.

Howes \& Herald. 2009. Emosi Anak. Yogyakarta: Ombak.

Nasional, D. P. (2006). Kurikulum Tingkat Satuan Pendidikan: Jakarta: Depdiknas.

No, U.-U. tahun 2003 tentang Sisdiknas. Bandung: Citra Umbara.

Pendidikan, T. P. B. P. (1993). Psikologi Pendidikan. Yogyakarta: UPP UNY.

Nana, Sudjana. Penilaian Hasil Proses Belajar Mengajar. Bandung: Remaja Rosdakarya. 